RESIDENT

\& FELLOW

SECTION

Section Editor

Mitchell S.V. Elkind,

MD, MS

\title{
Teaching NeuroImages: Amnesia due to fornix infarction
}

Address correspondence and reprint requests to Dr. Ludwig Gutmann, Robert C. Byrd Health Sciences Center, PO Box 9180 , WV University, Morgantown,

WV 26506-9180

lgutmann@wvu.edu

\section{Figure Diffusion-weighted axial (A) and sagittal (B) MRI demonstrating an acute infarction of the anterior fornices}
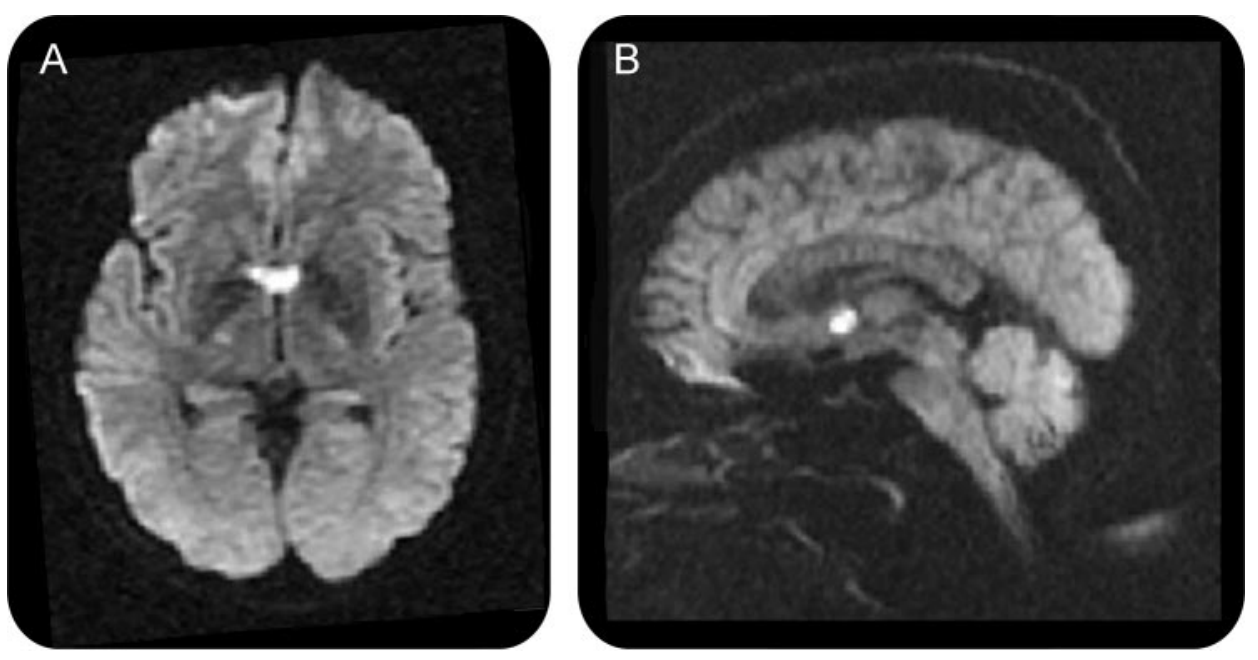

A 53-year-old right-handed teacher developed acute

Amnesia with infarction of anterior fornices confusion and short-term memory difficulties, including significant retrograde and anterograde amnesia. Intellect remained intact. She repeated phrases spoken recently without recall and asked inappropriate questions.

Mini-Mental State Examination was normal except for inability to recall any of 3 objects after 5 minutes. She had no other neurologic abnormalities. CT angiogram and transesophageal echocardiogram showed no thromboembolic source. Amnesia persisted 2 months later. (figure) has been rarely described. Small vessel disease of the perforating branches arising from the anterior cerebral or anterior communicating arteries $^{1,2}$ was the likely source of the infarct.

\section{REFERENCES}

1. Moudgil SS, Azzouz M, Al-Azzaz A, Haut M, Gutmann L. Amnesia due to fornix infarction. Stroke 2000;31:14181419.

2. Gade A. Amnesia after operations on aneurysms of the anterior communicating artery. Surg Neurol 1982;18: 46-49. 


\section{Neurology}

\section{Teaching NeuroImages: Amnesia due to fornix infarction}

B. L. Adamovich, G. Gualberto, T. Roberts, et al.

Neurology 2009;73; e86

DOI 10.1212/WNL.0b013e3181bd80af

This information is current as of October 26, 2009

\section{Updated Information \& Services}

References

Citations

Subspecialty Collections

Permissions \& Licensing

Reprints including high resolution figures, can be found at: http://n.neurology.org/content/73/17/e86.full

This article cites 2 articles, 1 of which you can access for free at: http://n.neurology.org/content/73/17/e86.full\#ref-list-1

This article has been cited by 1 HighWire-hosted articles: http://n.neurology.org/content/73/17/e86.full\#\#otherarticles

This article, along with others on similar topics, appears in the following collection(s):

All Cerebrovascular disease/Stroke

http://n.neurology.org/cgi/collection/all_cerebrovascular_disease_strok e

Infarction

http://n.neurology.org/cgi/collection/infarction

Memory

http://n.neurology.org/cgi/collection/memory

MRI

http://n.neurology.org/cgi/collection/mri

Stroke in young adults

http://n.neurology.org/cgi/collection/stroke_in_young_adults

Information about reproducing this article in parts (figures,tables) or in its entirety can be found online at:

http://www.neurology.org/about/about_the_journal\#permissions

Information about ordering reprints can be found online:

http://n.neurology.org/subscribers/advertise

Neurology ${ }^{\circledR}$ is the official journal of the American Academy of Neurology. Published continuously since 1951, it is now a weekly with 48 issues per year. Copyright . All rights reserved. Print ISSN: 0028-3878. Online ISSN: 1526-632X.

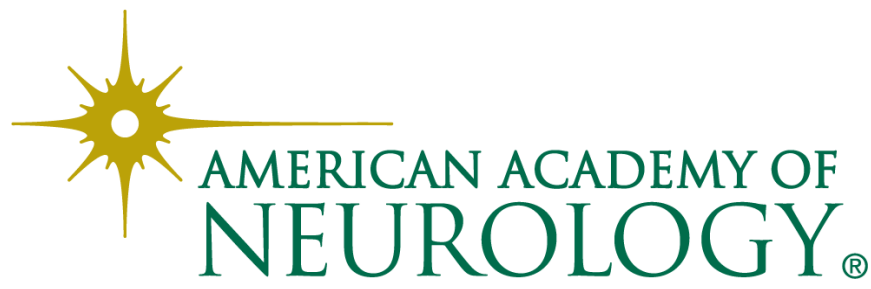

